\title{
Hafızaya Yönelik Müşteri Deneyimlerinin Müşteri Sadakatine Etkisi: Yeşil Oteller Örneği*
}

The Effects of Memorable Customer Experiences on Customer Loyalty: The Case of Green Hotels

\section{Üzeyir Kement \& Sinan Cavuşoğlu}

Beden Eğitimi ve Spor Eğitimi Bölümü, Bingöl Üniversitesi, Bingöl, Türkiye

\section{Özet}

Bu çalışmanın amacı yeşil yııdızlı otelleri ziyaret eden müşterilerin hafızaya dayalı deneyimlerinin anılarına ve sadakatlerine etkisinin belirlenmesidir. Araştırma evrenini Türkiye'de yeşil yıldız simgesi almış olan otelleri ziyaret eden otel müşterileri oluşturmaktadır. Araştırmada veri toplama aracı olarak anket kullanılmıştır. Araştırmada kolayda örneklem yöntemiyle 410 katııımcıya ulaşılmışır. Çalışmada kullanılan ölçeklere yönelik doğrulayııı ve keşifsel faktör analizleri uygulanmıştır. Hafızaya dayalı tüketici deneyimleri ölçeği dört alt boyuta (eğitim, eğlence, estetik ve kaçış) ayrılmışır. Araştırma bulgularına göre otel müşterilerinin estetik ve kaçış deneyimlerinin anılarını etkilediği, eğlence ve eğitim deneyimlerinin ise anılarını etkilemediği tespit edilmiştir. Ayrıca eğlence ve estetik anlayışları sadakat düzeylerini etkilerken eğitim ve kaçış boyutlarında aynı etki söz konusu değildir. Son olarak otel müşterilerinin yeşil yıldızlı otellerde edinmiş oldukları anılarının sadakatlerini olumlu yönde etkilediği belirlenmiştir.

Anahtar Kelimeler: Tüketici deneyimi, Sadakat, Yeşil otel

\section{Abstract}

The aim of this study is to determine the effects of memorable customer experiences on green hotel guests' memories and loyalty behaviours. The population of this study consists of the green hotels' customers in Turkey. Survey method was used as data collection tool in the research. 410 participants were reached by convenience sampling method in the study. Confirmatory and Exploratory Factor Analyses were applied to the scales used in the study. The memory based consumer experience scale is divided into four sub-dimensions (education, entertainment, aesthetics and escape). According to the results, aesthetics and escape has a positive effect on memories of guests. Education and entertainment hasn't a positive effect on memories of customers. Furthermore entertainment and aesthetics has a positive effect on loyalty. But education and escape hasn't same positive affect on loyalty.

Keywords: Customer experience, Loyalty, Green hotel

CONTACT : Üzeyir Kement, uzeyirkement@hotmail.com, ORCID ID: orcid.org/0000-0002-3190-9079; Sinan Çavuşoğlu, scavusoglu@ bingol.edu.tr, ORCID ID: orcid.org/0000-0001-9365-8677

Geliş Tarihi \& First Received : 19.09.2017

Kabul Tarihi \& Accepted : :29.10.2017

* Bu çalışma, 27-29 Nisan 2017 tarihinde Antalya'da düzenlenen "Innovation and Global Issues in Social Sciences" adlı uluslararası konferansta sunulan bildiri metninin tam metne dönüştürülmüş halidir. 


\section{Giriş}

Ekonomik ve politik sistemlerde küreselleşme, yoğun rekabet, tüketici talepleri ve değişimler, işletmeleri daha hızlı öğrenmeye ve çevresel değişikliklere adapte olmaya zorlamaktadır (Ginevičius ve Gudačiauskas, 2004, s. 143). Küresel ekonominin en hızlı büyüyen sektörlerinden bazıları deneyimlerin tüketimi ile ilgilidir (Pine ve Gilmore, 1999, s. 185). Sternberg (1997, s. 955), deneyimi, turizm sektörünün öncelikle sahnelenen bir tecrübe satışı olarak görmesi nedeniyle, turizmin başlangıcında ön plana çıkarmaktadır. Deneyim, turizm endüstrisi tarafından sunulan önemli bir fayda olarak kabul edilmesine rağmen, bu endüstride deneyimsel pazarlamanın kullanımı çok iyi bir şekilde uygulanamamıştır (Yuan ve Wu, 2008, s. 390).

Deneyimin ortaya çıkışı kazayla değil, kaçınılmaz bir eğilim olarak görülmektedir (Zhang, 2009, s. 28). Knutson ve Beck'e (2004, s. 3) göre, üç durum işletmeler için önemli kıstas haline gelmiştir. Bunlardan ilki teknolojinin tüketicileri zorlaması ve rekabeti arttırması; ikincisi, müşterilere uygun hizmetlerin sunulması ve son olarak da farklılaşma ve müşteri sadakatinin arttırılmasıdır. Bu durum giderek müşteri deneyimlerini yöneten hizmet firmaları için önemli bir endişe kaynağı olmuştur (Zomerdijk ve Voss, 2010, s.17). Zomerdijk ve Voss'a (2011) göre, tüketici deneyimi, önemli bir alandır ve birçok hizmet kuruluşu için tüketici duygularını tasarlamak yeni bir konudur. Son yıllarda pazarlama biliminde toplumsal anlayışın hakim olmasıyla birlikte, üreticilerin artık çevre dostu ürünlere yoğunlaştıkları görülmektedir. Turizm sektöründe bu kapsamda konaklama işletmelerinde "yeşil otel" konsepti geliştirilmiştir.

Yeşil yıldızlı otellerde yeşil yıldız simgesi, T.C. Kültür ve Turizm Bakanlığı'nın başlattığı "Çevreye Duyarlı Konaklama Tesisleri" projesi ve "Sürdürülebilir Turizm" kapsamında; çevreye duyarlı konaklama tesislerine verilen bir tür "Çevre Etiketi» uygulamasıdır. 22.09.2008 tarih ve 27005 sayılı Resmi Gazetede yayımlanarak yürürlüğe giren Turizm İşletmesi Belgeli Konaklama Tesislerine Çevreye Duyarlı Konaklama Tesisi Belgesi Verilmesine Dair Tebliğ (Tebliğ No:2008/3) doğrultusunda verilmektedir (Kültür ve Turizm bakanlığı, 2017). Çevrenin korunması, çevre bilincinin geliştirilmesi ve turistik konaklama işletmelerinde çevreye duyarlı yapılaşmanın ve işletmecilik özelliklerinin teşvik edilmesi amaçlanmıştır. Su tüketiminde tasarruf sağlamak, doğal kaynakların doğru kullanımını teşvik etmek, enerji verimliliğinin artırılmasına yardımcı olmak, çevreye zararlı maddelerin tüketiminin azaltılmasına yardımcı olmak, yenilenebilir enerji kaynaklarının teşvik edilmesini sağlamak, konaklama işletmelerinin çevreye duyarlı şekilde planlanmalarını sağlamak, tesis çalışanlarının bilinçlenmelerini sağlamak, iş gücünün en verimli şekilde kullanımını sağlamak, T.C. Kültür ve Turizm Bakanlığ1 tarafından sağlanan Elektrik Enerjisi Desteğinden faydalanmak ve sürdürülebilir rekabet üstünlügü elde etmek için önemlidir (TUYUP, 2017).

$\mathrm{Bu}$ çalışmanın amacı, yeşil yıldızlı otel işletmelerini tercih eden tüketicilerin konakladıkları sürece yaşamış oldukları deneyimin anılarına ve sadakatlerine etkisinin belirlenmesidir. Ayrıca tüketicilerin anılarının sadakatlerine etkisinin incelenmesi amaçlanmaktadır. Tüketici deneyimlerinin özellikle hafızaya yönelik olan türleri dikkate alınarak yapılan bu araştırma, işletmelerin sunmuş oldukları hizmetlerin 
yanında psikolojik açıdan bireye sağlamış olduğu faydaya odaklanması bakımından önemlidir. Çalışmanın evrenini, Türkiye'de yer alan yeşil yıldız simgeli otelleri ziyaret eden misafirler oluşturmaktadır.

\section{Kuramsal Çerçeve}

\subsection{Deneyimsel Pazarlama ve Boyutları}

Schmitt'e (1999, s. 62) göre geleneksel pazarlama, tüketicileri işlevsel özellikler ve faydalarla ilgilenen karar mercileri olarak görür. Buna karşılık, deneyimsel pazarlama ise, tüketicileri, zevkli deneyimler elde etmekle ilgilenen akılcı ve duygusal bireyler olarak görmektedir. Deneyimsel pazarlama, geleneksel pazarlamadan farklı olarak, yalnızca ürün kategorileri ve rekabet ile değil, aynı zamanda tüketicilerin özellikleri ve araştırma yöntemleriyle ayrılmış olan bir alandır (Yuan ve $\mathrm{Wu}, 2008$, s. 388). Holdbrook ve Hirschman (1982, s. 132) deneyimsel pazarlamanın, geleneksel pazarlamaya aykırı olmadığını aksine, geleneksel pazarlamayla bütünleşik bir düşünce olarak ele alınması gerektiğini ifade etmişlerdir. Yuan ve Wu'ya (2008, s. 388) göre deneyim, deneyimsel pazarlamanın ana bileşenidir. İşletmeler genellikle müşterilerinin, sahip oldukları ortamlardaki atmosfer ve farklı uyaranlar ile deneyimlenme imkanı sağlarlar. Deneyim sonucunda müşterilerin farklı algıları olur ve bu uyarılara tepki verir. Bu durum işletmeler hakkında çeşitli algılamaların gelişmesine yardımcı olur. Müşterilerin algıları, işletmelerin yaptıkları pazarlama çabalarının sonucunda gerçekleşir.

Williams'a (2006, s. 483) göre tüketiciler, bir otelde kalabilirler, bir restoranda yemek yiyebilirler veya seyahat etmek istedikleri yerlere gitmek gibi deneyimlere sahip olurlar. Driver ve Toucher (1970) deneyimi; planlama, varış yeri terk etme, varış yeri deneyimleme, geri dönme ve hatırlama olmak üzere beş farklı evreye ayırmıştır. Müşterilerin bu evrelerdeki deneyimleri, özellikle üçüncü aşamada değişebilir. Çünkü müşterilerin deneyimleri karmaşıktır ve işletmeler tarafından kontrol edilebilir ve kontrol edilemeyen faktörler de dahil olmak üzere birçok faktörden etkilenir (Yuan ve $\mathrm{Wu}, 1978$, s. 390).

Deneyimsel pazarlama, müşterilerin, bir işletmede faaliyette bulunduktan sonra, mal veya hizmet satın alma ve bunun devamında tekrar satın almanın geliştirilmesidir. Deneyimsel pazarlama, müşterileri daha hızlı ve daha olumlu satın alma kararları vermeye motive eder (Farias, Aguiar ve Melo, 2014, s. 98). Deneyimler, bir ürünün, bir markanın veya bir şirketin değerini arttırır. Bununla birlikte, deneyimsel pazarlama, ürünlerin ve hizmetlerin kalitesini ve işlevlerini gözden kaçırmaz; aksine, müşterilerin duygularını arttırır ve teşvik hissi uyandırır. Deneyimsel pazarlamanın temel noktası, ürünlerin özünü ortaya çıkarmak ve daha sonra ürün değerini artıran ve müşterilerin satın alma kararlarını vermesine yardımcı olan maddi olmayan, fiziksel ve etkileşimli deneyimi uygulamaktır (Williams, 2006, s. 485).

Yuan ve Wu (2008, s. 391) deneyimsel pazarlamanın, Ford Motor Company'den Kuzey Hawaii Topluluk Hastanesine kadar farklı endüstrilerdeki tüm işletmelere uygulanabileceğini söylemiştir. Williams (2006, s. 486), deneyimsel pazarlamanın, müşterileri daha hızlı ve daha olumlu satın alma kararları vermeye motive edeceğini 
belirtmiştir. Bazı yazarlar deneyim pazarlamasını veya müşteri deneyimlerini daha dar bir şekilde görmektedirler ve deneyim kavramını yalnızca etkileşimlere, ilişkilere veya olay bağlamlarına uygulamaktadırlar (Schmitt, 2010, s. 62). Örneğin, Lasalle ve Britton (2002, s. 30), deneyimsel pazarlamayı, bir müşteri ile bir ürün, bir şirket veya onun temsilcisi arasında reaksiyona giden bir etkileşim veya bir dizi etkileşimler bütünü olarak tanımlamaktadır. Kishka (2003; Akt. Schmitt, 2010, s. 63), deneyimsel pazarlamayı müşteri geribildirimlerini ölçmek ve yönetmek için sistematik bir yaklaşım olarak kullanmak olduğunu söylemiştir. Gentile, Spiller ve Noci (2007, s. 397) deneyimsel pazarlamayı, müşterinin beklentileri ile firma ile etkileşimden gelen uyaranlar ve sunumun veya temas noktaları arasındaki karşılaştırmaya bağlı olan bir durumun ifadesi şeklinde tanımlamışlardır.

Tüm bu bilgiler ışı̆̆ında konaklama işletmeleri için deneyimsel pazarlama; otel misafirlerinin işletmenin sunmuş olduğu ürünleri deneyimlemeleri sonucu misafirlerde duyusal, duygusal, düşünsel, davranışsal ve ilişkisel olarak meydana getirdiği sonuçlarla misafirlerin gelecekteki davranışlarını şekillendirme çabası olarak ifade edilebilir. Yeşil yıldızlı otellerde misafirlere sunulan ürünlerde toplumsal pazarlama odaklı kullanım farklılıkları vardır. Örneğin, otel işletmesinin odalarda kartlı sistemle açılan ve kapanan elektrik kullanması, sensörlü muslukları kullanması, yiyecek ve içecek birimlerinde atıkları ayrıştırarak hayvan barınaklarına göndermesi gibi farklılıklar yeşil yıldızlı otel işletmelerini diğer konaklama işletmelerinden ayıran hususlardır. Otel misafirleri için sosyal sorumluluk taşıyan ve gelecek nesillere aktarılabilecek bir ürün veya ürün kullanım süreci geliştiren konaklama işletmeleri deneyim bakımından tüketici zihninde daha farklı bir bakış açısını yaratabilir. Zira bu toplumsal pazarlama anlayışlı tutum ve davranışlar tüketicilere farklı geleceği ve insanlığın geleceğini tehdit etmeyen zararsız kullanımlar sunduğu için akılda kalıcılığ daha yüksek olabilmektedir.

Tüketiciler bir ürünü kullanımı sonucu ürüne yönelik farklı boyutlarda deneyimlenebilirler. Örneğin bir konaklama işletmesinin markasına yönelik misafirin duygusal bağı olabilir. Bu bağ sonucu misafirin otelde konaklaması veya o oteldeki diğer imkân ve olanaklardan faydalanması daha çok duygusal açıdan ele alınabilir. Zira misafirin o otelde yaşadıkları aklına otelin markasını getirebilecektir. Schmitt (1999, s. 53), deneyimsel boyutu 5 farklı şekilde belirlemiştir. Bu boyutlar; duyusal, duygusal, düşünsel, davranışsal ve ilişkisel olarak beşe ayrılmaktadır.

Duyusal deneyim; beş duyu organımızla elde edilen duyusal deneyimlerdir. İşletmelerde ürünleri belirlemek, müşterileri motive etmek ve ürünlere değer katmak için kullanilabilir (Schmitt, 1999, s. 61). Duygusal deneyim müşteri deneyiminin, duygu ve duyguların yaratılması yoluyla duygusal sistemini içeren bir bileşenidir (Gentile, Spiller ve Noci, 2007, s. 398). Schmitt' e göre (1999, s. 61) duygusal deneyim, bir markayla bağlantılı pozitif ruh hallerinden, güçlü duygularına kadar uzanan duygusal deneyimler geliştirme amacına yönelik olarak müşterilerin hisleri ve duygularına hitap etmektedir. 
Düşünsel deneyim düşünme veya bilinçli zihinsel süreçlerle bağlantılı müşteri deneyiminin bir bileşenidir. Bu deneyim müşterilerin yaratıcılıklarını kullanmaya yardımcı olmaktadır (Gentile, Spiller ve Noci, 2007, s. 398). Schmitt'e (1999, s. 62) göre davranışsal deneyim, fiziksel deneyimlerini hedefleyerek, onlara alternatif unsur yapma yollarını, alternatif yaşam biçimlerini ve etkileşimleri gösteren müşterilerin hayatlarını iyileştiren bir durumu simgeler. İlişkisel deneyim, bireyin kendini geliştirme isteğine hitap etmektedir (örneğin, gelecekte "ilişkide bulunmak istediği ideal benlik"). Bireysel olarak başkaları tarafından olumlu algılanmaya duyulan ihtiyacı vurgulamaktadır ve kişiyi daha geniş bir sosyal sistemle ilişkilendirir.

\subsection{Tüketici Deneyim Alanları}

Pine ve Gilmore (1998) deneyim yaşatmanın tüketicileri eğlendirmeye değil, onların ilgisini çekmeye yönelik olduğunu belirtmektedirler. Tüketici deneyimleri, belirli bilgi, değer veya davranışları sosyal olarak sergilemek veya eğitmek, eğlendirmek ve kaçış, görsel veya estetik bir karşılaşma sunmak için fırsat yaratabilir (Holbrook, 1982; Pine ve Gilmore 1998). Prahalad'a (2004) göre değer, mallara eklenmez ya da hizmetler tarafından ortaya konmaz, ancak aktif katılım yoluyla oluşturulan gerçek kişiselleştirilmiş deneyimler içine gömülüdür.

Pine ve Gilmore (1998, s. 102), iki kutupsal yapı arasında aktiften pasife kadar değişen müşteri katılımını ve özümsemeden sarmalanmaya kadar değişen bağlantı deneyimlerinin gerçekleştiğini belirtmektedir. Örneğin, sinemada film izleyen biri pasif olurken, restoranda yemek yiyen birisi aktif olmaktadır. Deneyimsel pazarlama mevcut sunuma eğlence unsurunu eklediğinde tüketiciyi eğlendiren bir anlayıştan ziyade tüketicinin ilgisini çekmeyi amaçlamaktadır. Bir deneyim birkaç farklı boyutla müşterilerin ilgisini çekebilir. Bu boyutlar Şekil 1'de görülebilmektedir.

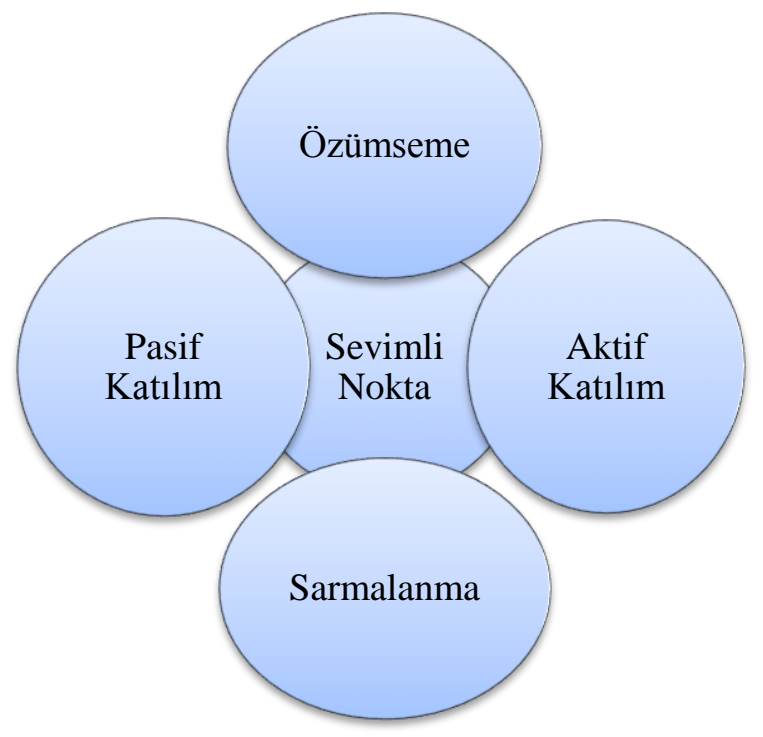

Şekil 1: Tüketici Deneyim Alanları

Kaynak: Pine ve Gilmore, 1999, s. 30 
Yatay dairelerdeki birinci boyut konuk katılımını ifade etmektedir. Konuk katılımını ifade etmek için; müşterilerin doğrudan etkisi olmayan durumlar için pasif, müşterilerin deneyimlenen olaya doğrudan etkisi olan durumlara aktif tanımlaması kullanılmaktadır. Pasif katılıma örnek olarak olayı sadece izleyici ya da gözlemci olarak yaşayan senfoni konseri meraklıları düşünülebilir. Aktif katılım için ise; kendi deneyimlerini yaratmak üzere olaya aktif olarak katılan kayakçılar örnek gösterilebilir. Dikey eksendeki ikinci boyutta ise, müşterileri olayla birleştiren bağlantı ya da çevresel ilişki boyutu yer almaktadır. Bağlantı ya da çevresel ilişkiyi ifade etmek için ise; özümseme ve sarmalama alanları kullanılmıştır. Özümseme, deneyimi akla getirerek bir kişinin zihnini meşgul etme, sarmalama ise fiziksel ya da sanal açıdan deneyimin bir parçası olma anlamını taşımaktadır (Pine ve Gilmore, 1999, s. 31).

Tüketicileri olaylara katılmaya davet eden başarılı deneyimler oluşturmak için birey duyuları, duyguları, ruhu ve zihni tarafından çağrılmalıdır. Bu nedenle, markaların ürün veya hizmetlerinden olumlu bir şekilde karar almalarına neden olacak etkin bir tecrübeyi gerçekleştirmek için markaların doğru uyaranlara ve çevreye ihtiyaç duymaları gerekir (Zarem, 2000). Çeşitli deneyim alanları vardır (Petkus, 2004, s. 51; Pine ve Gilmore, 1999, s. 30). Pine ve Gilmore (1999, s. 30) eğlence, eğitim, kaçış ve estetik ile başlamak için dört deneyim alanının bulunduğunu belirtmiştir. Bu bilgiler doğrultusunda her bir ifadenin kesişmesiyle deneyimin dört alanı ortaya çıkmaktadır. Pine ve Gilmore (1998), iyi düzenlenmiş bir deneyimin güçlü/pozitif duygulara neden olduğunu ve bu duyguların turistlerin tutumlarını olumlu bir şekilde şekillendireceğini belirtmektedir. Pine ve Gilmore (1998)'un deneyim alanı modeli, iki seviyede farklılaşan tüketici deneyimlerinden oluşan dört alana sahiptir. Bu alanlar; i) müşteri katılım derecesi (pasif veya aktif katılım); ii) müşterinin olaya/performansa (özümsemeye karşı sarmalanma) bağlanma isteği. Dört tecrübe türü ise Eğlence (pasif/özümseme); Eğitim (aktif/özümseme); Kaçış (aktif/ sarmalanma); ve Estetik (pasif/sarmalanma)' tir (Hosany ve Witham, 2010).

\subsubsection{Eğlence Deneyimi}

Petkus' a (2004, s. 51) göre, deneyimlerin ilk alanı olan "eğlence" olayın özümsenmesi ve pasif katılımı içerir. Pine ve Gilmore'a (2011, s. 47) göre eğlence olarak ifade edilen deneyimler, genellikle bir gösteriyi seyrederken, müzik dinlerken ya da kitap okurken olduğu gibi, duyularıyla pasif olarak özümsenen deneyimlerdir. Deneyimin en eski biçimidir. En yaygın bilinen türüdür. Konaklama işletmelerinde de animasyon faaliyetleri, odalarda bulunan tv, oturma alanları, eşantiyon oyun malzemeleri, yiyecek ve içecek birimlerinde gerçekleştirilen renkli yiyecek ve içecek sunumları eğlence deneyimine örnek olarak gösterilebilir.

\subsubsection{Eğitim Deneyimi}

"Eğitim", deneyimsel etkinliğe aktif bir katılımı gerektirir. Örneğin, bir film seyrederken veya müzik dinlerken, eğlence deneyimi duyular tarafından pasif olarak emilir. Bununla birlikte, öğrencilerin bir sınıftaki bir öğretim elemanını dinlemesi durumunda, eğitim deneyimi, olaya zihin veya bedenle katılarak aktif bir şekilde 
gerçekleşir (Petkus, 2004, s. 51). Eğitim Alanındaki faaliyetler, katılımclların daha aktif olarak yer aldıkları, ancak sarmalamadan ziyade özümseme niteliğe sahip olanları içermektedir. Bu alanda, katılımcılar yeni beceriler kazanır veya sahip oldukları becerileri artırır. Kayak dersi alırken olduğu gibi tüketici bu deneyimin sonunda bilgilendirilmekte veya becerisini arttırmaktadır (Williams, 2006, s. 488). Özellikle yeşil yıldız simgesi almış olan konaklama işletmelerinde odalarda, lobide, yiyecek içecek biriminde, ön büro biriminde çeşitli doğayı korumaya yönelik bilgilendirme yazıları, araştırma sonuçları veya doğa dostu ürünler ve üzerinde oluşum süreçleri yer almaktadır. Bu tür ürünler aslında otel müşterilerini doğa dostu olmaya yönlendirirken diğer yandan farkındalıklarını sağlamaktadır. Dolayısıyla konaklama işletmelerinde eğitime en iyi örnek olarak gösterilebilir.

\subsubsection{Kaçış Deneyimi}

"Kaçış" deneyimi aktif bir katılımı ifade etmektedir. Ancak bu durum, eğitim deneyimine göre daha aktif bir katılımı ifade eder (Petkus, 2004, s. 51). Tipik örnekler arasında tema parkları, macera arazileri ve temalı gözde mekânlar yer alır (Hosany ve Witham, 2010, s. 8). Turizm sektörü kaçış deneyimleri için sayısız fırsatlar sunmaktadır ve tatiller tüketicilere "kaçış yardımı, sorun çözücü, güç tedarikçisi, enerji ve mutluluk" anlamına gelir (Krippendorf, 1987, s. 17). Diğer bir ifade ile tatil, günlük hayat tarzından psikolojik bir kaçış sağlamaktadır (Uriely, 2005). Bu bakımdan konaklama işletmeleri aslında bireylerin doğrudan monotonlaşan hayatlarından kaçışlarını sağladıkları yerlerdir. Konaklama işletmeleri kaçış deneyimi için bütünüyle bir örnek olabilir. Ayrıca doğa dostu tutum içinde olan tüketiciler için yeşil yıldızlı oteller, doğa ile iç içe olma veya betonlaşmanın verdiği zararı zihinsel olarak yok etmenin bir çaresi olarak düşünülebilir.

\subsubsection{Estetik Deneyimi}

"Estetik deneyim", pasif bir katılım gerektirir. Örneğin, kaçış bir bireyin bir eğlence parkını ziyaret etmesine örnek olarak kabul edilebilir, ancak bu kişinin bir müzeye yaptığı ziyaret ise estetik deneyime örnek gösterilebilir (Petkus, 2004, s. 51). Etkinlikler doğada daha pasif hale getirildiğinde olay estetik hale gelir. Estetik deneyiminde katılanların amacı sadece orada olmaktır. Bu tür deneyimlerde bireyler bir olayın ya da ortamın içine girerler ama bu olay ya da ortama hiç etki etmez ya da çok az etki ederler. Yani etkinliğe katılımları söz konusu değildir (Pine ve Gilmore, 1999, s. 35). Pine ve Gilmore' ye (1999) göre estetik deneyim, eğlence deneyiminden daha yoğun bir tecrübe gerektirir. Yine turistlerin kendilerini tecrübe edindikleri, ancak tecrübeye az miktarda aktif katılım ile çok sayıda turizm etkinliğinin estetik bir nitelikte olduğu sonucuna varmak kolaydır. Estetik deneyimlere örnek olarak sanat galerisi ya da bir müzeyi gezmek gösterilebilir. Yeşil oteller her işletme gibi öncelikle yapı estetiği ile otel müşterilerine estetik deneyim yaşatması mümkün olabileceği gibi, odalarda sensörlü ışıklandırma ve musluklarda sensörlü sistemlerin kullanılması da estetik deneyim olarak görülebilir. Zira yapı ve mimari sistemlerde daha öteye gidilmesi, zarafetin bina içinde dekorasyon üzerinde sunumu estetik deneyim için önemli olarak düşünülebilir. 
Bununla birlikte Pine ve Gilmore'a (1999, s. 39) göre, tüketicilerin en zengin deneyimleri dört deneyimin tüm yönlerini kapsamakta ve bu deneyimlerin buluştuğu "sevimli nokta" diye bir alan oluşmaktadır. Pine ve Gilmore (1999) çalışanların, çevreye dikkat etmeleri ve kulis alanlarına önem vermeleri nedeniyle, tüketicilere sunulan en zengin deneyimlerden biri olarak Walt Disney World örneğinden bahsetmişlerdir. Zira bütün deneyim alanlarına ilgili rekreasyon alanında örnekler mevcuttur. Dolayısıyla Williams'ın (2006, s. 488) da ifade ettiği gibi kazanılan deneyimin zengin olabilmesi bütün boyutların birleşmesine bağlıdır.

Brakus, Schmitt ve Zarontonello (2009, s. 54) dört deneyim kategorisini eleştirmektedir. Dolayısıyla bu alanların üçünü daha farklı şekilde kavramsallaştırmıştır. Deneyim alanlarını; duyusal/estetik, entelektüel/eğitsel ve duygusal/eğlendirici olarak değerlendirmektedirler. Addis (2005, s. 1), eğitim ve eğlence deneyimlerini bir araya getirmiş ve "eğitici-eğlence (edutainment)" kavramını önermiştir. Addis' e (2005) göre edutainment tüketicinin aynı anda eğlenebileceği ve öğrenebileceği kültürel tüketimin yenilikçi bir yorumu olarak düşünülebilir. Addis $(2005$, s. 4) ayrıca, edutainment' in, teknolojinin yardımı ile mesajları şimdi birden fazla duyuya çekecek bir şekilde dönüştürmek ve çok ağırlaştırmadan daha karmaşık içerik oluşturmak için mümkün olduğu kadar farklı deneyimler sunabileceğini de söylemektedir. Addis' in (2005) yapmış olduğu çalışmada deneyim alanlarının iki alanından yararlanılmıştır. Yeşil otelleri kapsayan bu çalışmada, deneyim alanlarının tamamı incelenmiştir. Brakus, Schmitt ve Zarontonello'un (2009) deneyim alanları sınıflaması ise konaklama işletmeleri için uygun olmama ihtimali nedeniyle araştırmada kullanılmamasına karar verilmiştir. Dolayısıyla araştırmada Pine ve Gilmore (1999) tarafında yapılan sınıflama dikkate alınarak ölçek geliştirilmiştir.

\subsection{Müşteri Sadakati}

Kandampully ve Suhartanto' ye (2000, s. 346) göre sadakatin genel tanımı, tercih edilen bir ürünün veya hizmetin tekrarlanan satın alımını teşvik edecek şekilde geri satın alım taahhüdüdür. Sadık müşteriler mümkün olduğunca aynı tedarikçilerden satın alır ve onlara karşı olumlu bir tutum içinde olması nedeniyle bu tedarikçileri başkalarına tavsiye eder. Oliver (1999, s. 35) müşteri sadakatini, gelecekte bir ürünü veya hizmeti sürekli olarak tekrar satın almak için güçlü bir taahhüt olarak tanımlarken, Pearson (1996, s. 147) ise tüketicilerin tutumsal yönüne dikkat çekerek; müşteri sadakatini olumlu tutumlara sahip olan tüketicilerin, geri satın almayı ve başkalarına ürünlerini/hizmetlerini önermeyi taahhüt ettiği düşüncesi olarak tanımlamaktadır. Dick ve Basu (1994, s. 100) ise yine tekrar satın alma eylemi üzerinden bir tanımlamaya giderek; müşteri sadakatini, bir şirketin ürünlerini tekrar satın alması şeklinde tanımlamıştır. Anderson ve Mittal' a (2000, s. 114) göre sadık müşteriler, firmalar için kritik öneme sahiptir. Çünkü mevcut müşterileri yeni müşterilere çekmekten daha az maliyetlidir. Sadık müşterilere sahip olmak, şirketlerin fiyat primini kullanmalarını sağlar. Buna ek olarak, sadık müşteriler çevrelerindeki insanlara güvenilir önerilerde bulunma eğilimindedir. Dolayısıyla müşterilerin ilgili üründen tatmin olması ve 
ürüne/işletmeye yönelik olumlu tutum oluşturması, müşteri sadakatinin ana öncüllerindendir (Jones, Mothersbaugh ve Beatty, 2000, s. 270).

Baloglu (2002) sadakatin iki temel yaklaşımla açıklandığını belirtmiştir. Bunlar davranışsal ve tutumsal yaklaşımlardır. Davranışsal bakış açısına göre, bağlılık bir davranış biçimidir. Daha geniş bir ifade ile birden fazla tekrarlanan satın alma eylemi bir sadakat göstergesidir. Tutumsal yaklaşımı ise bireylerin ürünü sunan işletme veya kişiler hakkında başkalarına olumlu yönde tavsiyelerde bulunması eylemidir. Daha geniş bir ifade ile tüketicilerin satın almayı tekrarlamasından ziyade, tedarikçilerinin hizmetlerini diğer müşterilere önermesidir. (Kursunluoglu, 2011, s. 53). Ayrıca Kim, Park ve Jeong (2004, s. 147) sadakati 3 temel yaklaşımla ele almış ve üçüncü yaklaşım olarak davranışsal ve tutumsal yaklaşımların birleşimi olan karma yaklaşım modelinin olduğunu belirtmişlerdir. Bowen ve Chen (2001, s. 213) bu düşünceyi destekleyerek, bu yaklaşımı müşterinin ürünü tekrar satın alması ve ilgili işletmeye ait ürünleri başkalarına tavsiye etmesi şeklinde belirtmişlerdir.

Yang, Chen ve Chien'e (2014, s. 178) göre hizmet, müşterileri tatmin ediyorsa, satın alma sıklığ 1 artarken, alternatif aramalarda bir azalma meydana getirebilir. Güven ve ilişki değeri, müşteri sadakatinde öncel olan hususlardır (Walter, Mueller, Helfert ve Wilson, 2002). İlişki değeri, dolaylı olarak müşteriyi tatmin, taahhüt ve güven yoluyla etkilerken, aynı zamanda müşteri tekrar satın alımını da doğrudan etkiler (Ulaga ve Eggert, 2006, s. 323). Lee, Hsiao ve Yang' a (2010, s. 40) göre müşteri bağl1lı̆̆1, doğru müşteriyi çekme, onları satın alma, sık sık satın alma, daha yüksek miktarlarda satın alma ve daha fazla müşteri getirme ile ilgilidir. Dolayısıyla iş başarısında vazgeçilmez bir konudur. Fornell (1992) için müşteri sadakati, pazarlama biliminde birçok kavramla tanımlanmaktadir.

Konaklama işletmeleri hem mal hem hizmet sunması bakımından birçok tüketici veya tüketici grubu için farklı anlamlar içerebilmektedir. Örneğin bir tüketici işletmenin yatakları, ek hizmetleri (sauna, bar ve mutfak çeşitleri, bulunduğu konumun manzarası vb.) gibi somut varlıklara önem vererek tekrar tekrar satın alma gerçekleştirebilirken, başka bir tüketici çalışanların tutumu, hizmet esnekliği, hızı vb. hususlara önem vermektedir. Dolaysıyla konaklama işletmeleri hem sadık müşterilerin oluşabileceği alanlarken hem de tavsiye için ideal ürünlere sahip yerlerdir. Yeşil oteller de hem bir konaklama işletmesinin bütün işlevlerini taşıması hem de doğa dostu eylemleri ile tüketiciler için farklılık oluşturabilmektedir. Dolayısıyla sadakat ölçümü için uygun olduğu söylenebilir.

\subsection{Araştırma Modelinin Geliştirilmesi}

Son yıllarda, günlük yaşamlarından kaçmak ve eğlenmek için doğal veya egzotik yerlerde bulunan konaklama işletmelerine giden bireylerde önemli bir artış gözlemlenmektedir (Ali, Omar ve Amin, 2013, s. 10). Pine ve Gilmore (1999), tüketim deneyimlerinin daha güçlü anılara ve daha sonra yapılan olumlu değerlendirmelere yol açtığını ifade etmektedirler. Sınırlı sayıda bilim adamı bu durumu incelemiş ve tüketici deneyim alanlarının tüketici anıları üzerindeki olumlu etkilerini desteklemişlerdir 
(Gilmore ve Pine, 2002; Quadri-Felitti ve Fiore, 2013). Bu bağlamda, Tung ve Ritchie (2011) misafirlerin bilgisini artırabilecek bir hedonik ve eğlendirici deneyimin, olumlu hatıralar, arkadaşlar ve ailelere yapılan ziyaretler ve öneriler gibi olumlu davranışlarla sonuçlanabileceğini belirtmektedirler. Oh, Fiore ve Jeong (2007) ve Hosany ve Witham (2010) aynı zamanda tüketici deneyim alanları ile pozitif anıların ve sadık davranışların arasında önemli bir ilişki olduğunu gözlemlemişlerdir.

Ali, Hussain ve Ragavan (2014) yaptıkları çalışmada müşteri deneyiminin dört yönünün tüketici anıları ve sadakatleri üzerinde olumlu yönde etkisinin olduğunu ortaya koymuşlardır. Ayrıca, müşteri deneyiminin dört yönünün, geliştirilen anıların müşteri bağlılığını da etkilediğini de gözlemlemişlerdir.

Pine ve Gilmore (1999; 2011), tüketim deneyimlerinin müşteri tatminine yol açtığını iddia etmişlerdir. Oh, Fiore ve Jeang (2007) estetik deneyim ve memnuniyet arasında anlamlı bir ilişki keşfetmiştir. Hosany ve Witham (2010), tüketim deneyimlerinden estetik ve eğlencenin müşteri tatminine önemli ölçüde katkıda bulunduğunu belirtmişlerdir. Getz ve Carlsen (2008), turistlerde kaçış deneyim boyutu ile olumlu bir deneyim için eğitim etkinliklerine eğlenceli sunumlara ihtiyaç duyduklarını ileri sürmüştür. Yuan ve Jang (2008) iyi tasarlanmış hizmetin tüketici niyetini artırdığını açılamışlardır.

Araştırmanın amacı, yeşil yıldızlı otel müşterilerinin konaklama süresince yaşamış oldukları deneyimin (eğitim, estetik, eğlence ve kaçış deneyimleri) anılarına ve sadakatlerine etkisinin belirlenmesidir. Ayrıca müşterilerin yeşil otellerde konakladıkları sürece edinmiş oldukları anıların sadakatlerine etkisinin belirlenmesidir. Tüketici deneyimlerinin özellikle hafızaya yönelik olan türleri dikkate alınarak yapılan bu araştırma, işletmelerin sunmuş oldukları hizmetlerin yanında psikolojik açıdan bireye sağlamış olduğu faydaya odaklanmaktadır. Bu kapsamda geliştirilen hipotezler ve araştırma modeli şu şekildedir;

$\mathrm{H}_{1}$ : Otel müşterilerinin eğitim deneyimleri anılarını olumlu yönde etkiler.

$\mathrm{H}_{2}$ : Otel müşterilerinin eğlence deneyimleri anılarını olumlu yönde etkiler.

$\mathrm{H}_{3}$ : Otel müşterilerinin estetik deneyimleri anılarını olumlu yönde etkiler.

$\mathrm{H}_{4}$ : Otel müşterilerinin kaçış deneyimleri anılarını olumlu yönde etkiler.

$\mathrm{H}_{5}$ : Otel müşterilerinin eğitim deneyimleri sadakatlerini olumlu yönde etkiler.

$\mathrm{H}_{6}$ : Otel müşterilerinin eğlence deneyimleri sadakatlerini olumlu yönde etkiler.

$\mathrm{H}_{7}$ : Otel müşterilerinin estetik deneyimleri sadakatlerini olumlu yönde etkiler.

H8: Otel müşterilerinin kaçış deneyimleri sadakatlerini olumlu yönde etkiler.

$\mathrm{H}_{9}$ : Otel müşterilerinin anıları sadakatlerini olumlu yönde etkiler. 


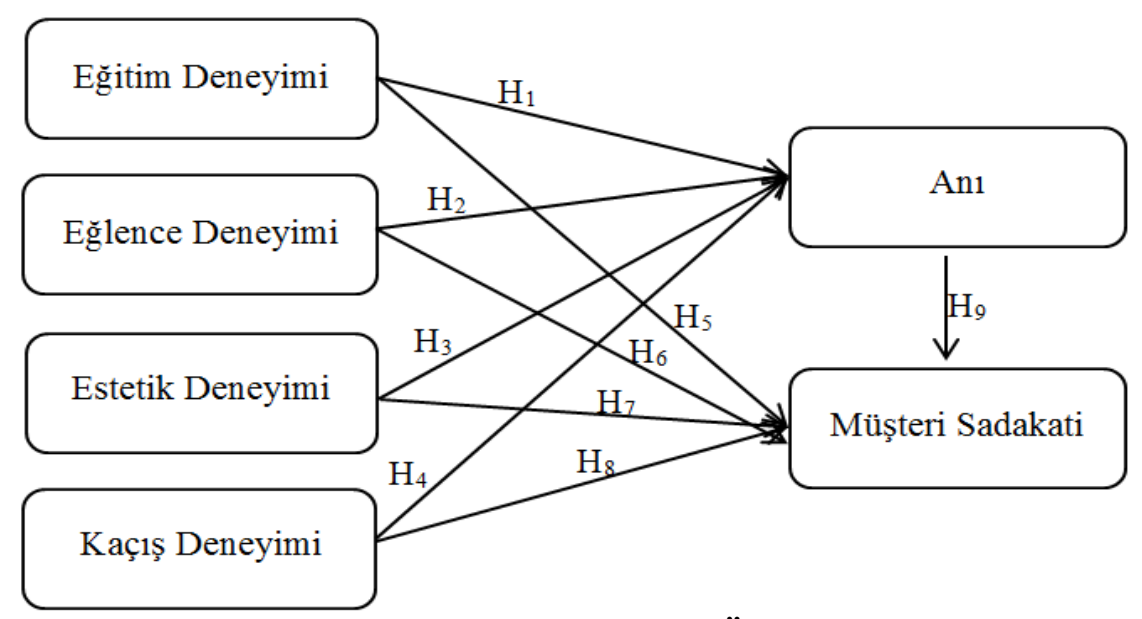

Şekil 2: Araştırma Model Önerisi

\section{Yöntem}

\subsection{Evren ve Örneklem}

Yeşil yıldızlı otel müşterilerinin deneyimlerinin anılarına ve sadakatlerine etkisinin incelenmesi amacıyla yapılmakta olan bu araştırma amacına göre incelendiğinde uygulama araştırmaları olarak değerlendirilmektedir (Dinler, 1998, s. 9). Araştırma, otel müşterilerinin deneyimlerini ve sadakat düzeyleri ve nedenlerini ortaya koyduğu içim yöntem olarak tanımlayıcıdır. Amaçlar doğrultusunda araştırma değişkenleri arasında hipotezler kurulmuştur. Bu hipotezler ile etki analizi yapıldığı için araştırma açıklayıcı niteliktedir (Clark, Wood, Wilkie ve Riley, 1998, s. 9).

Araştırmanın evrenini Türkiye'de yeşil yıldız simgesi almış olan otel işletmelerini ziyaret eden bireyler oluşturmaktadır. Araştırma evreninde 2017 Nisan ayı itibariyle 399 yeşil yıldız simgesi almış olan otel bulunmaktadır (Kültür ve Turizm, 2017). Ancak bu otelleri ziyaret eden müşteri sayısına yönelik bir veri bulunmamaktadır. Evreni temsil eden işletmeleri ziyaret eden müşteri sayısına yönelik bir verinin olmaması nedeniyle kolayda örneklem metoduyla 436 adet katılımcıya anket dağıtılmıştır. Tam olarak doldurulmamış olan 26 anket çıkartılmış, sonuç olarak 410 katılımcıya ulaşılmıştır. Ölçeklendirilmiş sorular, literatür taraması ve uzman görüşleri doğrultusunda belirlenmiş, otel müşterilerine yapılmadan önce, 30 kişiden oluşan müşteri grubu üzerinde ön uygulama yapılmış ve yanlış anlaşılan ya da anlaşılmayan ifadeler düzeltilmiştir.

Araştırmada veri toplama aracı olarak kullanılan ankette; hafızaya dayalı tüketici deneyimleri ölçeği, müşteri anıları ve müşteri sadakati ölçeğinin soruları Ali, Hussain ve Ragavan (2014) ve Nadiri ve Günay'ın (2013) çalışmalarından uyarlanmıştır. Ölçeklere ilişkin ifadeler araştırmanın amacına yönelik anlam açısından değişiklik olmayacak şekilde düzenlenmiştir. Anket formu iki bölümden oluşmaktadır. Birinci bölümde katılımcıların demografik özelliklerine ilişkin sorular yer alırken ikinci bölümde hafızaya dayalı tüketici deneyimleri, anı ve müşteri sadakati ölçeklerine ilişkin ifadeler yer almaktadır. Ölçeklere ilişkin sorular 5'li Likert derecelemesine uygun olarak sıralanmıştır. 


\subsection{Verilerin Analizi}

Araştırmanın demografik özellikleri açıklandıktan sonra araştırma modeline yönelik geçerlik ve güvenilirlik analizleri gerçekleştirilmiştir. Güvenilirlik analizinde Crombach Alpha ve Composite Reliability testlerinden faydalanırken, geçerliliğini belirlemek için soru formları yapılan pilot çalışma kapsamında değerlendirilip yanlış anlaşılan ya da anlaşılmayan ifadeler düzenlenmiştir. Yapı geçerliliğini belirlemek için; uyum geçerliliği (AVE) ayrım geçerliliğine (doğrulayıcı ve keşifsel faktör analizleri) bakılmıştır. Araştırma sorularının dağılımlarını otaya koymak için kurtosis ve skewness değerleri incelenmiştir. Araştırma hipotezlerinin ölçümü için yol analizinden yararlanılmıştır.

\section{Araștırma Bulguları}

\subsection{Demografik Bulgular}

Katılımcıların demografik özelliklerini açıklayan bulgulara bakıldı̆̆ında katılımcıların \%54,6'sının erkek, \%45,4'ünün bayan olduğu görülmektedir. Katılımcıların yaşlarına göre dağılım incelendiğinde en çok katılımcının \%21,5 yüzdesi ile 55-64 yaş aralığı olduğu görülmektedir.

Tablo 1: Demografik Özelliklere İlişkin Frekans Analizi

\begin{tabular}{llll}
\hline Demografik Değişkenler & & $\mathrm{n}$ & $\%$ \\
\hline \multirow{2}{*}{ Cinsiyet } & Erkek & 224 & 54,6 \\
& Kadın & 186 & 45,4 \\
\hline \multirow{4}{*}{ Yaş } & $<18$ & 32 & 7,8 \\
& $18-24$ & 39 & 9,5 \\
& $25-34$ & 51 & 12,4 \\
& 35,44 & 58 & 14,1 \\
& $45-54$ & 76 & 18,5 \\
& $55-64$ & 88 & 21,5 \\
\multirow{2}{*}{ Medeni Durumu } & $65 \leq$ & 66 & 16,1 \\
& Evli & 277 & 67,6 \\
& Bekâr & 133 & 32,4 \\
\hline \multirow{5}{*}{ Eğitim } & İlköğretim & - & - \\
& Lise & 19 & 4,6 \\
& Ön lisans & 104 & 25,4 \\
& Lisans & 168 & 41,0 \\
& Master & 84 & 20,5 \\
\hline \multirow{4}{*}{ Aile Gelir Durumu } & Çok düşük & 10 & 2,4 \\
& Düşük & 23 & 5,6 \\
& Orta & 80 & 19,5 \\
& Yüksek & 119 & 29,0 \\
& Çok yüksek & 178 & 43,0 \\
\hline
\end{tabular}

Katılımcların \%41'inin lisans düzeyinde eğitim aldığı, \%29'unun gelir durumunun yüksek olduğu ve $\% 67,6$ 'sının evli olduğu görülmektedir. 


\section{2. Ölçme Modeli Testi ve Tanımlayıcı İstatistikler}

Araştırma kapsamında oluşturulan hipotezlerin test edilmesinden önce var olan ölçeklerin kavramları ölçme durumunu test etmek için hafızaya dayalı tüketici deneyimleri, anı ve müşteri sadakati değişkenlerine yönelik Doğrulayıcı Faktör Analizi yapılmıştır. Yapılan Doğrulayıcı Faktör Analizi sonuçlarına göre, modelin kabul edilebilir uyum sergilediği gözlemlenmektedir ( $\chi^{2} / d f ; 1,396$, RMSEA:0.082, NFI: 0.952, CFI:0.986, IFI: 0.986, GFI; 0,942) (Şimşek, 2007, s. 14; Kline, 1998; Bryne, 2001; Stevens, 2012; Schermelleh-Engel ve Moosbrugger, 2003).

Ayrıca, soru formundaki ölçeklere ilişkin tanımlayıcı istatistikler, güvenilirlik ve geçerliliğe ilişkin değerler hesaplanmıştır. Bu değerler tablo 2'de detaylı olarak gösterilmektedir. Alfa katsayısının güvenilirlik hesaplamada bir takım kısıtları olduğu düşünülmektedir. Buna göre ölçekte yer alan bütün ifadelerin güvenilirliğe eşit derecede katkı sağlaması bu kısıtlar arasında görülmektedir (Bollen, 1989; Shook, Ketchen, Hult ve Kacmar, 2004, s. 400). Shook, Ketchen, Hult ve Kacmar (2004) bileşik güvenilirlik (CR) (composite reliability) değerinin güvenilirlik hesaplamada daha iyi bir seçim olduğu ifade edilmektedir. Tablo 2'de görüldüğü üzere CR'nin 0.60'in üzerinde olması ile ifadeler güvenilir olup (Bagozzi ve Yi, 1988, s. 82), "içsel tutarlılığa sahiptir" (Dursun vd., 2013, s. 300).

Yapı geçerliliği (construct validity), ayrım (discriminant validity) ve uyum (convergent validity) geçerlilikleri ile belirlenmektedir (Peter, 1981, s. 136). Tablo 2'de gösterildiği üzere bu araştırmada kullanılan ölçeklerin ayrım geçerliliği ortalama açıklanan varyans (AVE) (Average Variance Extracted) değerlerinin 0.50'in üzerinde olmasıyla belirlenmektedir (Fornell, Larcker, 1981, s. 46). Ayrıca ölçeklerin her birinin AVE değerinin korelasyon değerinin karesinden büyük olması ile gerekmektedir (Fornell, Larcker, 1981; Sirakaya-Turk, Ekinci ve Martin, 2015).

Tablo 2: Tanımlayıcı İstatistikler

\begin{tabular}{|c|c|c|c|c|c|c|c|c|c|}
\hline \multicolumn{2}{|c|}{ Değişkenler } & \multirow{2}{*}{$\begin{array}{c}\text { CR } \\
, 82\end{array}$} & \multirow{2}{*}{$\begin{array}{l}\text { AVE } \\
, 54\end{array}$} & \multirow{2}{*}{$\frac{1}{1}$} & \multirow[t]{2}{*}{2} & \multirow[t]{2}{*}{3} & \multirow[t]{2}{*}{4} & \multirow[t]{2}{*}{5} & \multirow[t]{2}{*}{6} \\
\hline 1 & Eğitim & & & & & & & & \\
\hline 2 & Estetik & ,92 & ,75 & ,078 & 1 & & & & \\
\hline 3 & Eğlence & ,91 & 73 &, $307^{* *}$ &, $380^{* *}$ & 1 & & & \\
\hline 4 & Kaçış & ,91 & ,72 & ,068 & $462^{* *}$ & $229^{* *}$ & 1 & & \\
\hline 5 & Anı & ,90 & ,75 & ,060 &, $483^{* *}$ &, $206^{* *}$ &, $518^{* *}$ & 1 & \\
\hline 6 & Sadakat &, 90 & ,70 & ,041 &, $398^{* *}$ & ,093 &, $363^{* *}$ &, $505^{* *}$ & 1 \\
\hline
\end{tabular}

Uyum geçerliliği, ölçekte yer alan ifadelerin ait oldukları faktörlere yüklenme düzeylerinin 0.50'den fazla olması sonucu elde edilmektedir (DFA) (Bagozzi ve Yi, 1988, s. 82). DFA ile ölçekte yer alan ifadelerin ölçülmek istenen faktör ile anlamlı düzeyde ilişkili olduğu tespit edilmektedir (Peter, 1981, s. 136). Tablo 3'te görüldüğü üzere ifadelerin ait oldukları ölçeklere yüklenme düzeyleri genel olarak 0.50'den fazladır. Tablo 3'te ayrıca ölçekte yer alan değişkenlerin her bir ifadesine ilişkin ortalama, standart sapma ve keşifsel faktör analizi (KFA) yükleri verilmektedir. 
Tablo 3: Değişkenlerin Ortalaması, Standart Sapması, Faktör Yükleri, Dağılımları ve Güvenilirlik Katsayıları

\begin{tabular}{|c|c|c|c|c|}
\hline Değişkenler & $\mathbf{X}^{2}$ & S.S. & DFA & KFA \\
\hline \multicolumn{5}{|l|}{ Hafızaya Dayalı Tüketici Deneyimleri $(\alpha: 0,86)$} \\
\hline \multicolumn{5}{|l|}{ Ĕ̈itim $(\alpha: 0,73)(K: 2,977$, S:-1,484) } \\
\hline 1. Bu otelde yaşadığım deneyim sayesinde daha çok bilgilendim. & 4,02 & 1,10 & 651 & ,743 \\
\hline 2. Bu otelde kaldığım süre boyunca çok şey öğrendim. & 3,93 & 1,13 & 617 & 753 \\
\hline 3. Merakım beni yeni şeyler öğrenmeye tetikliyor. & 3,92 & 1,16 &, 554 & ,739 \\
\hline 4. Bu otelde kalmak gerçekten öğretici bir deneyimdi. & 4,02 & 1,05 & ,726 & ,705 \\
\hline \multicolumn{5}{|l|}{ Ĕ̆lence $(\alpha: 0,90)(K: 0,348, S:-0,918)$} \\
\hline 1. Oteldeki aktivitelere katılmak ve izlemek zevkliydi. & 3,98 & 1,12 & ,850 & ,862 \\
\hline 2. Oteldeki aktivitelere katılmak ve izlemek büyüleyiciydi. & 3,93 & 1,12 & 879 & 883 \\
\hline 3. Oteldeki aktivitelere katılmak ve izlemek eğlenceliydi. & 3,90 & 1,07 & ,792 & 807 \\
\hline 4. Oteldeki aktivitelere katılmak ve izlemek keyifliydi. & 3,95 & 1,12 & ,863 & ,872 \\
\hline \multicolumn{5}{|l|}{ Estetik $(\alpha: 0,93)(K: 0,117$, S:-0,878) } \\
\hline 1. Ben gerçekten adapte olduğumu hissediyorum. & 3,82 & 1,20 & ,885 & 875 \\
\hline 2. Burada olmak gerçekten çok hoştu. & 3,75 & 1,16 & ,846 & ,861 \\
\hline 3. Ortam çok ilgi çekiciydi. & 3,83 & 1,13 & 882 & , 851 \\
\hline $\begin{array}{l}\text { 4. Ortamın sahip olduğu tasarım dikkat çekici bir görünüme sahipti. } \\
\text { Kaçıs }(\alpha: 0,90)(K: 0,917, S:-1,111)\end{array}$ & 3,90 & 1,15 & ,911 & 887 \\
\hline 1. Burada farklı bir karaktere sahip olduğumu hissediyorum & 3,99 & 1,10 & 844 & 839 \\
\hline $\begin{array}{l}\text { 2. Burada faklı bir zaman veya mekânda yaşıyormuşum gibi } \\
\text { hissediyorum. }\end{array}$ & 3,82 & 1,12 & ,855 & 875 \\
\hline $\begin{array}{l}\text { 3. Burada yaşadığım deneyim kendimi başka biri gibi hayal etmeme } \\
\text { izin veriyor }\end{array}$ & 3,84 & 1,14 & ,804 & ,845 \\
\hline 4. Burada günlük rutin hayatımdaki her şeyi unuttum. & 3,86 & 1,17 & ,851 & ,855 \\
\hline \multicolumn{5}{|l|}{ An1 $(\alpha: 0,88)(K: 0,228, S:-0,912)$} \\
\hline 1. Ziyaret ettiğim bu otel ile ilgili muhteşem anılara sahibim. & 3,86 & 1,25 & 832 & 874 \\
\hline 2. Bu otelde yaşadığım deneyimi unutmak istemiyorum. & 3,65 & 1,18 & 843 & ,854 \\
\hline 3. Bu otelle ilgili birçok olumlu şeyler hatırlayacağım. & 3,72 & 1,21 & 867 & ,883 \\
\hline \multicolumn{5}{|l|}{ Müşteri Sadakati $(\alpha: 0,89)(\mathrm{K}: 0,348$, S:-0,950) } \\
\hline 1. Bu oteli başkalarına tavsiye edeceğim. & 3,83 & 1,29 & ,868 & 818 \\
\hline 2. Bu oteli ziyaret etmeye yönelik başkalarını teşvik edeceğim. & 3,59 & 1,17 & ,780 & ,846 \\
\hline 3. Bu oteli tekrar ziyaret etmek istiyorum. & 3,64 & 1,16 & 774 & ,842 \\
\hline Ben bu otele kesinlikle tekrar geleceğim. & 3,72 & 1,20 & 853 & ,843 \\
\hline
\end{tabular}

Tablo incelendiğinde hafızaya dayalı tüketici deneyimleri alt boyutlarından eğitim faktörüne ilişkin 1. ve 4. ifadelerin ortalamaları aynı ve diğerlerinden daha yüksektir. Eğlence alt boyutuna ilişkin ifadelerin her birinin ortalamaları birbirine yakın ve DFA ve KFA değerleri yüksek görünmektedir. Estetik alt boyutunun değerleri incelendiğinde ortalamalar 3,50' nin üzerinde, standart sapmaları 1' in üzerinde ve DFA ve KFA yükleri yüksektir. Kaçış alt boyutu ise diğer alt boyutlarla benzer sonuçlara sahiptir. Araştırma değişkenlerinden anı boyutunun değerlerine bakıldığında, her bir sorunun ortalamasının 3,50'nin üzerinde olduğu gözlemlenmektedir. Müşteri sadakati değişkeninin de ortalama değerleri yine 3,50'nin üzerindedir. Araştırmada kullanılan hafızaya dayalı tüketici deneyimleri, anı ve müşteri sadakati ölçeklerinin Keşifsel Faktör Analizi ile gruplandırılmasının yapılması gerekliliğini belirlemek amacıyla KMO ve Barlett testleri yapılmıştır. Barlett Küresellik Testi anlamlı $(\mathrm{p}<, 001)$ ve KMO testi sonucu 
0,88 çıkmıştır. Ölçeklerin Crombach Alpha değerleri incelendiğinde her birinin güvenilirlik katsayısının 0,70 'in üzerinde olduğu, dolayısıyla iyi bir güvenilirlik katsayısına (Hair, Black, Babin, Anderson ve Tatham, 2006, s. 778) sahip olduğu görülmektedir. Ayrıca tabloda basıklık (K) (Kurtosis), çarpıklık (S) (Skewness) değerleri verilmektedir. Basıklık ve çarpıklık değerleri ölçeklerin normal dağılıma sahip olduklarını göstermektedir. Zira her bir ölçeğin değerleri -3 ile +3 arasında (Shao, 2002) siralanmaktadir.

Hipotezlerin test edilebilmesi için yol analizi yapılmıştır. Buna göre, model kabul edilebilir uyum sergilemektedir ( $\chi^{2} / \mathrm{df} ; 1,396$, RMSEA:0.082, NFI: 0.952, CFI:0.986, IFI: 0.986, GFI; 0,942). Ayrıca modelde yer alan yollar ve standardize katsayı değerleri Tablo 4 'te gösterilmektedir. Buna göre, eğitim ve eğlence alt boyutlarının anı değişkenine, eğitim ve kaçış alt boyutlarının sadakat değişkenine ait $t$ değerleri 0,05 anlamlılık düzeyinde 1,96'nın altındadır. Dolayısıyla, belirtilen değişkenlere yönelik tanımlanan etkiler bir sonraki analizde yer almamaktadır.

Tablo 4: Yol Analizi

\begin{tabular}{lccccc}
\hline \multicolumn{2}{c}{ Önerilen Hipotezlere İlişkin Yollar } & Yol Katsayısı & Etki Değeri & S.E & P \\
\hline $\mathrm{H}_{3}:$ Estetik & $\longrightarrow$ Anı & 0,32 &, 312 &, 053 & $* * *$ \\
$\mathrm{H}_{4}:$ Kaçış & $\longrightarrow$ Anı & 0,42 &, 468 &, 063 & $* * *$ \\
$\mathrm{H}_{6}:$ Eğlence & $\longrightarrow$ Sadakat & $-0,10$ &,- 121 &, 059 &, 042 \\
H7: Estetik & $\longrightarrow$ Sadakat & 0,24 &, 249 &, 063 & $* * *$ \\
$\mathrm{H}_{9}$ Anı & S Sadakat & 0,48 &, 515 &, 065 & $* * *$ \\
\hline
\end{tabular}

$* * *: 0,001$

Yol analizinin tekrar yapılması ile elde edilen model iyi olarak nitelendirilmektedir ( $\chi$ 2/df;1380, RMSEA:0.030, NFI: 0.952, CFI:0.986, IFI: 0.986, GFI; 0,941, FMIN:,739). Yol analizi sonuçlarına göre, estetik (H3) ve kaçışın (H4) müşteri anılarına, eğlence (H6) ve estetiğin (H7) müşteri sadakatine ve müşteri anılarının (H9) müşteri sadakatine etkisine yönelik önerilen hipotezler desteklenmektedir. Diğer taraftan eğitim (H1) ve eğlencenin (H2) müşteri anılarına, eğitim (H5) ve kaçışın (H8) müşteri sadakatine etkisine yönelik oluşturulan hipotezler ise desteklenmemiştir. Elde edilen yeni model şekil 3 'te gösterilmektedir.

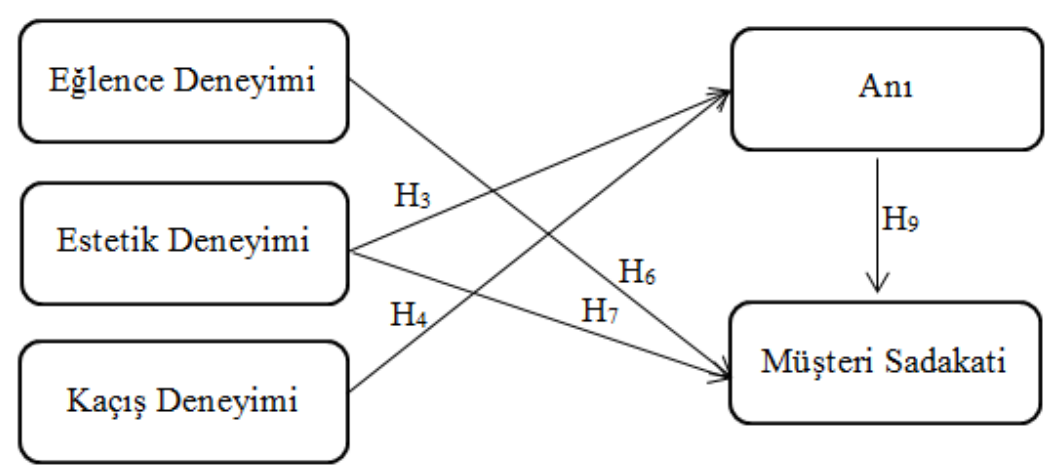

Şekil 3: Araştırma Modeli 
Yol analizi sonuçlarına göre, yeşil yıldızlı otelleri ziyaret eden otel müşterilerinin sadakat düzeylerinde müşterilerin otelde yaşadıkları anıları ve otellerin estetik dizaynının zihne yansıması ve eğlence anlayışının negatif düzeyde olmasının (e;-,121) etkisi olduğu söylenebilir. Diğer bir ifade ile ilgili otel işletmelerinin doğa dostu olmasının ve işletmecilik anlayışında müşterileri de ailesinden gördüğünü hissettiren bir yaklaşım sergiliyor olmalarının etkisi olduğu görülmektedir. Ayrıca otel müşterilerinin sadakatlerinin yaklaşı \% 30 'luk kısmının (R2: 0,298) altında anı ve estetik ve eğlence deneyimleri yatmaktadır. Geriye kalan \%70'lik kısım ise başka nedenlerden kaynaklanmaktadır.

Ayrıca müşterilerin anılarını oluşturan tüketici deneyimleri incelendiğinde estetik ve kaçış deneyimlerinin etkisi olduğu görülmektedir. Yeşil otelleri ziyaret eden misafirlerin estetik deneyimlerinin ve kaçış deneyimlerinin müşteri anısına etkisi \%35 düzeyindedir ( $R^{2}:$ 0,345). Geriye kalan \%65'lik dilim ise farklı nedenlerden kaynaklanmaktadır. Müşteri anılarına bir işletmeye yönelik müşterinin sahip olduğu bilgi (Hartman ve Spiro, 2005), ürün ve hizmetin kalitesi (Srinivasan, Anderson ve Ponnavolu, 2002) veya farklı oluşu (Rust ve Oliver, 2000) etki edebilir.

\section{Sonuç ve Öneriler}

Çalışma hafızaya yönelik müşteri deneyimlerinin anılara ve müşteri sadakatine ve anıların sadakate etkisini belirlemek amacıyla hazırlanmıştır. Yeşil yıldızlı otelleri ziyaret eden otel müşterilerine yapılan anket yoluyla elde edilen veriler doğrultusunda; eğitim, eğlence, estetik ve kaçış boyutu ve anı şeklinde beş boyut doğrulanmıştır. Bu faktörler ile sadakat ve müşteri anıları arasındaki ilişkinin ölçülmesi amacıyla analizler yapılmıştır.

Analiz sonuçlarına göre, otel müşterilerinin estetik deneyimlerinin anılarını (H3) ve kaçış deneyimlerinin anılarını olumlu yönde etkilediği $(\mathrm{H} 4)$; eğlence deneyimlerinin sadakatlerini (H6) ve estetik deneyimlerinin sadakatlerini olumlu yönde etkilediği (H7); otel müşterilerinin anılarının sadakatlerini olumlu yönde etkilediği (H9) belirlenmiştir. Malezya'da bulunan bir resort oteldeki konukların deneyimlerini ve tüketim sonrası etkilerini değerlendirmeyi amaçlayan araştırma sonucunda müşteri deneyiminin dört alanının (eğlence, eğitim, estetik ve kaçış) da anılarını ve sadakatini etkilediğini belirlemişlerdir. Dört alanın, sonuçta sadakat davranışlarını etkileyebileceği ve tüketicilerin anılarını geliştirebileceği sonucuna varmışlardır. Çalışma bu yönü ile Ali, Hussain ve Ragavan (2014) tarafından hazırlanan çalışma ile aynı doğrultudadır. Diğer taraftan eğitim (H1) ve eğlencenin (H2) müşteri anılarına, eğitim (H5) ve kaçışın (H8) müşteri sadakatine etkisine yönelik oluşturulan hipotezler ise desteklenmemiştir. Bu durum Ali, Hussain ve Ragavan (2014) tarafından hazırlanan çalışmadan farklıdır. Çalışmanın yeşil yıldızlı otellerde yapılması bu farklılığı yaratan bir unsur olarak görülebilir.

Hosany ve Witham'ın (2010) çalışmalarında ise, Singapur'dan Hong Kong'a giden "Rhapsody of the Seas" isimli bir gemide iki haftalık tatile çıkan turistlere tüketici deneyimlerini, anılarını, genel olarak algılanan kalite, tavsiye etme niyeti ve 
memnuniyetlerini ölçebilmek için araştırma gerçekleştirilmiştir. Söz konusu araştırma sonuçlarına göre, deneyimin dört alanının tavsiye etme niyeti üzerinde doğrudan bir etkisinin olduğu belirlenmiştir. Buna ek olarak, memnuniyetin tüketici deneyimleri ile tavsiye etme niyeti arasındaki ilişkiye kısmen aracılık ettiği görülmüştür. Çalışma bu yönüyle değerlendirildiğinde Hosany ve Witham' in (2010) yaptığı çalışma ile aynı doğrultudadır.

Ayrıca yapılan diğer çalışmalarda ise Kara ve Çiçek (2015) Nevşehir ili Kozaklı ilçesinde 4 ve 5 yıldızlı termal otellerde gerçekleştirdikleri çalışmada deneyimsel boyutların (duyusal, duygusal, düşünsel, davranışsal ve ilişkisel) müşterinin sosyo demografik özelliklerine göre termal turizm tercihlerine etkisini belirlemeye yönelik çalışmalarında düşünsel ve duygusal deneyimlerin etkili olduğu sonucuna ulaşmışlardır. Yine Yuan ve $\mathrm{Wu}$ (2008), deneyimsel pazarlamanın duygusal ve işlevsel değerler yoluyla tatmin ve sadakati teşvik ettiğini belirlemişlerdir. Mcintosh ve Siggs'in (2005) Yeni Zelanda'nın Güney adasındaki Nelson Butik otellerinde yaptığı araştırmada deneyimsel boyutların müşteri sadakatine etkisinin olduğu sonucuna varılmıştır. Ayrıca Saltık (2011) Muğla şehrinde yer alan çeşitli destinasyonları ziyaret eden turistlerle yapılan görüşmeler sonucunda, turistlerin tüm deneyim boyutlarını yaşadığı sonucuna ulaşmıştır. Ayrıca deneyimlerin tüketici davranışları üzerinde çeşitli etkilere sahip olduğu belirlenmiştir. Nadiri ve Günay'ın (2011) Kuzey Kıbrıs'ta Gloria Jean's Coffees işletmesinde yapmış olduğu çalışmada ise işletmelerin deneyimsel pazarlama çabalarının müşteri memnuniyetine olumlu katkı sağladığı ve satış sonrasında pozitif davranışa neden olabilecek durumların olabileceğini belirlemişlerdir. Deneyimsel boyutların tekrar ziyaret etme niyetine sebep olabileceği sonucuna varmışlardır. Karadeniz, Pektaş ve Topal (2013) İstanbul'da bir alışveriş merkezi müşterilerine yaptığ araştırmada, deneyimsel pazarlama ve hizmet kalitesinin müşteri sadakati ve müşteri memnuniyeti ile pozitif yönlü bir ilişkisi olduğu anlaşılmıştır. Bu çalışmalar değerlendirildiğinde, eğlence deneyimlerinin (H6), estetik deneyimlerinin (H7) ve anıların sadakati olumlu yönde etkilediği (H9) sonuçları desteklenmektedir. Genel olarak, ölçüm sonuçları güvenilirlik ve geçerlilik açısından kabul edilebilir niteliktedir. Korelasyon ve yol analizi teknikleri ile bu sonuçlar desteklenmiştir.

$\mathrm{Bu}$ çalışma sadece yeşil otellerle sınırlı kalmıştır. Bundan sonraki çalışmalarda resort, kıyı ve şehir otellerinde çalışma gerçekleştirilebilir ve kıyaslama yapılabilir. Örneklem sayısı da bu doğrultuda arttırılabilir. Addis (2005) yaptığı çalışmada eğitim ve eğlence deneyimlerini bir araya getirmiş ve "eğitici-eğlence (edutainment)" kavramını ortaya koymuştur. İlgili boyut bu çalışmada kullanılmamıştır. Ancak ilerleyen çalışmalarda edutainment deneyimi de eklenerek yeşil otellerde tüketici deneyimleri incelenebilir. Ayrıca tüketici deneyim alanları yerine boyutları kapsamında da yeşil otellerde yeni araştırmalar gerçekleştirilebilir. 


\section{Kaynakça}

Addis, M. (2005). New technologies and cultural consumption-edutainment is born! European Journal of Marketing, 39(7/8), 729-736.

Ali, F., Hussain, K. \& Ragavan, N. A. (2014). Memorable customer experience: examining the effects of customers experience on memories and loyalty in Malaysian resort hotels. Procedia-Social and Behavioral Sciences, 144, 273-279.

Ali, F., Omar, R. \& Amin, M. (2013). An examination of the relationships between physical environment, perceived value, image and behavioural Intentions: A SEM approach towards Malaysian resort hotels. Journal of Hotel and Tourism Management, 27(2), 9-26.

Anderson, E. W. \& Mittal, V. (2000). Strengthening the satisfaction-profit chain. Journal of Services Research.3, 107-120.

Bagozzi, R. P. \& Yi, Y. (1988). On the evaluation of structural equation models. Journal of the academy of Marketing Science, 16(1), 74-94.

Baloglu, S. (2002). Dimensions of customer loyalty: Separating friends from well Wishers. Cornell Hotel and Restaurant Administration Quarterly, 43(1), 47-59.

Bollen, K. A. (1989). A new incremental fit index for general structural equation models. Sociological Methods \& Research, 17(3), 303-316.

Bowen, J. T. \& Chen, S. L. (2001). The relationship between customer loyalty and customer satisfaction. International journal of contemporary hospitality management, 13(5), 213-217.

Brakus, J. J., Schmitt, B. H. \& Zarantonello, L. (2009). Brand experience: what is it? How is it measured? Does it affect loyalty? Journal of Marketing, 73(3), 52-68.

Bryne, B. M. (2001), Structural equation modeling with AMOS, EQS, and LISREL: Comparative approaches to testing for the factorial validity of a measuring instrument, International Journal of Testing, 1(1), 55-86.

Clark, M., Riley, M., Wilkie, E. \& Wood, R. C. (1998). Researching and writing dissertations in tourism and hospitality. International Thomson Business Press, London.

Farias, S. A., Aguiar, E. C., \& Melo, F. V. S. (2014). Store atmospherics and experiential marketing: A conceptual framework and research propositions for an extraordinary customer experience. International Business Research, 7(2), 87.

Dick, A. S. \& Basu, K. (1994). Customer loyalty: toward an integrated conceptual framework. Journal of Academy of Marketing Sciences, 22, 99-113. 
Driver, B. L. \& Toucher, R. C. (1970). Toward a behavioral interpretation of recreation of planning. Element of Outdoor Recreation Planning, 9-31.

Fornell, C. (1992). A National customer satisfaction barometer: The Swedish experience, Journal of Marketing, 56(1), 6-21.

Fornell, C. \& Larcker, D. F. (1981). Evaluating Structural Equation Models with Unobservable Variables and Measurement Error, Journal of Marketing Research, 18(1), 39-50.

Gentile, C., Spiller, N. \& Noci, G. (2007). How to sustain the customer experience: An overview of experience components that co-create value with the customer. European Management Journal, 25(5), 395-410.

Getz. D. \& Carlsen, J. (2008). Wine tourism among generations X and Y. Tourism 56(3), 257-270.

Gilmore J. H. \& Pine, B. J. (2002). Differentiating hospitality operations via experiences: Why selling services is not enough. Cornell Hotel and Restaurant Administration Quarterly, 43(3), 87-96.

Ginevičius, R. \& Gudačiauskas, D. (2004). Brand valuation model. Journal of Business Economics and Management, 5(3), 143-153.

Gültekin, B. (2010). Faydacı-Hedonik Güdüler, Göz Atma Ve Marka Bilinirliğinin Anlık Alışverişe Etkisine İlişkin Bir Model Önerisi, Yayınlanmamış Doktora Tezi, İşletme Ana Bilim Dalı, Sosyal Bilimler Enstitüsü, Hacettepe Üniversitesi, Ankara.

Güney, H. \& Karakadılar, İ. (2015). Starbucks firmasının deneyimsel pazarlama uygulamalarının incelenmesi, İ.Ü. İşletme Fakültesi Işletme İktisadı Enstitüsü Yönetim Dergisi, 26, 131-155.

Hair, J. F., Black, W. C., Babin, B. J., Anderson, R. E. \& Tatham, R. L. (2006). Multivariate Data Analysis, Pearson Prentice Hall. Upper Saddle River, New Joursey.

Hartman, K. B., \& Spiro, R. L. (2005). Recapturing store image in customer-based store equity: a construct conceptualization. Journal of Business research, 58(8), 1112-1120.

Holbrook, M. B. \& Hirschman, E. C. (1982). The Experiential Aspects of Consumption: Customer Fantasies, Feelings, And Fun. Journal of Consumer Research, 9(2), 132-140.

Hosany, S. \& Witham, M., (2010). Dimensions of cruisers' experiences, satisfaction, and intention to recommend. Journal of Travel Research, 49(3), 351-364.

Jones, M. A., Mothersbaugh, D. L. \& Beatty, S. E. (2000). Switching barriers and repurchase intentions in services. Journal of Retail, 76(2), 259-274. 
Kandampully, J. \& Suhartanto, D. (2000). Customer loyalty in the hotel industry: The role of customer satisfaction and image. International Journal of Contemporary Hospitality Management, 12(6), 346-351.

Kara, M. \& Çiçek, B. (2015). Deneyimsel pazarlama ve satın alma karar sürecine etkisi: termal turizm sektöründe bir uygulama. Gümüşhane Üniversitesi Sosyal Bilimler Enstitüsü Elektronik Dergisi, 6(13), 177-200.

Karadeniz, M., Pektaş, G. Ö. E. \& Topal, Y. K. (2013). The Effects Of Experiential Marketing And Service Quality On Customer Satisfaction And Costomer Loyalty At Shopping Centers. Journal of Naval Science and Engineering, 9(1), 46-66.

Kim, M. K., Park, M. C. \& Jeong, D. H. (2004). The effects of customer satisfaction and switching barrier on customer loyalty in Korean mobile telecommunication services, Telecommunication Policy, 28(2), 145-159.

Kishka, J. (2003). How to manage the customer experience. Customer Management Magazine (July/August).

Kline, R. B. (1998). Software review: Software programs for structural equation modeling: Amos, EQS, and LISREL. Journal of psychoeducational assessment, 16(4), 343-364.

Knutson, B. J. \& Beck, J. A. (2004). Identifying the dimensions of the experience construct: development of the model. Journal of Quality Assurance in Hospitality \& Tourism, 4(34), 23-35.

Konuk, G. (2014). Deneyimsel Pazarlama, Detay Yayıncılık, Ankara.

Krippendorf, J. (2010). The Holiday Makers (Understanding the impact of leisure and travel),Butterworth Heinmann, Biritish Library.

Kursunluoglu, E. (2011). Customer service effects on customer satisfaction and customer loyalty: A field research in shopping centers in İzmir city-Turkey. International Journal of Business and Social Science, 2(17), 52-59.

Lasalle, D. \& Britton, T. A. (2002). Priceless: Turning Ordinary Products into Extraordinary Experiences. Boston: Harvard Business School Press.

Lee, M. S., Hsiao, H. D. \& Yang, M. F. (2010). The study of the relationships among experiential marketing, service quality, customer satisfaction and customer loyalty. International Journal of Organizational Innovation (Online), 3(2), 352-378.

Mcintosh, A. J. \& Siggs, A. (2005). An exploration of the experiential nature of boutique accommodation. Journal of Travel Research, 44(1), 74-81.

McNickel, D. (2004). Hands on Brands: Feel Them, Do Them, Be Them. New Zealand Marketing Magazine, May, 10-15. 
Myers, W. H. (2000). A structural equation model of family factors associated with adolescent depression. Yayınlanmamıs doktora tezi, Memphis Üniversitesi.

Nadiri, H. \& Gunay, G. N. (2013). An empirical study to diagnose the outcomes of customers' experiences in trendy coffee shops. Journal of Business Economics and Management, 14(1), 22-53.

Nagasawa, S. (2008). Customer Experience Management Influencing on Human Kansei to Management of Technology. The TQM Journal, 20(4), 312-323.

Odabaşı, Y. (2004). Müşteri İlişkilerinden Müşteri Deneyimine; Starbucks Fal da Bakar m1? Sabah Business, 22, 12-13, http://yavuzodabasi.wordpress.com, Erişim: 10.03.2017.

Oh, H., Fiore, A. M. \& Jeong, M. (2007). Measuring experience economy concepts: tourism applications. Journal of Travel Research, 46(2), 119-131.

Oliver, R. L. (1999). Whence consumer loyalty? Journal of Marketing, 63, (özel sayı), 33-44.

Pearson, N. (1996). Building brands directly: creating business value from customer relationships, Macmillan Business, 20(6), 68-82.

Peter, J. P. (1981). Construct Validity: A Review of Basic Issues and Marketing Practices. Journal of Marketing Research, XVIII, 133-145.

Petkus, E. (2004). Enhancing the application of experiential marketing in the arts. International Journal of Nonprofit and Voluntary Sector Marketing, 9(1), 49-56.

Pine, B. J. \& Gilmore, J. H. (1998). Welcome to the experience economy. Harvard Business Review, 76, 97-105.

Pine, B. J. \& Gilmore, J. H. (2011). The experience economy. Harvard Business Press.

Pine J., B. \& Gilmore, J. H. (1999). The experience economy: work is theatre and every business a stage. Harvard Business School Press Boston, Massachusetts.

Rust, R. T., \& Oliver, R. L. (2000). Should we delight the customer? Journal of the Academy of Marketing Science, 28(1), 86-94.

Quadri-Felitti, D. L. \& Fiore, A. M. (2013). Destination loyalty: Effects of wine tourists' experiences, memories, and satisfaction on intentions. Tourism and Hospitality Research, 13(1), 47-62.

Schermelleh-Engel, K., Moosbrugger, H. \& Müller, H. (2003). Evaluating the fit of structural equation models: Tests of significance and descriptive goodness-of-fit measures. Methods of psychological research online, 8(2), 23-74.

Schmitt, B. H. (1999). Experiential marketing: How to get customers to sense, feel, think, act, and relate to your company and brands. New York: Free Press. 
Schmitt, B. (2010). Experience Marketing: Concepts,Frameworks And Consumer Insights, Foundations and Trends in Marketing, 5(2), 55-112.

Shao, A. T. (2002). Marketing research. An Aid to Decision Making. Cincinnati.

Shook, C. L., Ketchen, D. J., Hult, G. T. M. \& Kacmar, K. M. (2004). An assessment of the use of structural equation modeling in strategic management research. Strategic management journal, 25(4), 397-404.

Sirakaya-Turk, E., Ekinci, Y. \& Martin, D. (2015). The efficacy of shopping value in predicting destination loyalty. Journal of Business Research, 68(9), 1878-1885.

Srinivasan, S. S., Anderson, R., \& Ponnavolu, K. (2002). Customer loyalty in e-commerce: an exploration of its antecedents and consequences. Journal of retailing, 78(1), 41-50.

Sternberg, E. (1997). The iconography of the tourism experience. Annals of Tourism Research, 24(4), 951-969.

Stevens, J. P. (2012). Applied multivariate statistics for the social sciences. Routledge.

Şimşek, Ö. F. (2007). Yapısal eşitlik modellemesine giriş: Temel ilkeler ve LISREL uygulamaları. Ankara: Ekinoks.

T.C. Kültür ve Turizm Bakanlığı, (2017). Çevreye Duyarlı Konaklama Tesisleri, http://yigm.kulturturizm.gov.tr/TR,9579/turizm-tesisleri.html, adresinden erişildi. (Erişim Tarihi: 19.05.2017).

T.C. Kültür ve Turizm Bakanlığı, (2017). Turizm İşletmesi Belgeli Konaklama Tesislerine Çevreye Duyarlı Konaklama Tesisi Belgesi Verilmesine Dair Tebliğ, http://www.resmigazete. gov.tr/eskiler/2008/09/20080922-3.htm, adresinden erişildi. (Erişim Tarihi: 03.03.2017).

T.C. Kültür ve Turizm Bakanlığı, (2017). Yeşil Yıldız Simgesi, http://tuyup.turizm.gov.tr, adresinden erişildi. (Erişim tarihi: 31.05 .2017$)$.

TUYUP Turizm, (2017). Turizm Sektöründe İşverenlerin ve Çalışanların Uyum Yeteneklerinin Artırılması Projesi, http://tuyup.turizm.gov.tr/Pages/GreenStar.aspx? (Erişim Tarihi: 03.05.2017).

Tung, V. W. S. \& Richie, J. R. B. (2011). Exploring the essence of memorable tourism experiences. Annals of Tourism Research, 48(4), 1367-1386.

Ulaga, W. \& Eggert, A. (2006). Relationship value and relationship quality: Broadening the nomological network of business-to-business relationships. European Journal of marketing, 40(3/4), 311-327.

Uriely, N. (2005). The tourist experience: Conceptual developments. Annals of Tourism research, 32(1), 199-216. 
Walter, A., Mueller, T. A., Helfert, G. \& Wilson, D. T. (2002). Delivering relationship value: Key determinant for customers' commitment. (Retrieved March, 4, 2004).

Williams, A. (2006). Tourism and Hospitality Marketing: Fantasy, Feeling and Fun. International Journal of Contemporary Hospitality Management, 18(6) ,482-495.

Yang, C. C., Chen, P. S. \& Chien, Y. H. (2014). Customer expertise, affective commitment, customer participation, and loyalty in B\&B services. International Journal of Organizational Innovation, 6(4), 174-183.

Yuan, Y. \& Wu, C. (2008). Relationships Among Experiential Marketing, Experiential Value and Customer Satisfaction. Journal of Hospitality \& Tourism Research, 32(3), 387410 .

Zarem, J. E. (2000). Experience marketing. Folio: The Magazine for Magazine Management, $1(3), 28-32$.

Zhang, Y. (2009). A study of corporate reputation's influence on customer loyalty based on PLS-SEM model. International Business Research, 2(3), 28-35.

Zomerdijk, L. G. \& Voss, C. A. (2010). Service design for experience-centric services. Journal of Service Research, 13(1), 67-82.

Zomerdijk, L. G. \& Voss, C. A. (2011). NSD processes and practices in experiential services. Journal of product innovation management, 28(1), 63-80. 